\title{
HUBUNGAN PENGGUNAAN APLIKASI PESAN ANTAR MAKANAN ONLINE DENGAN FREKUENSI MAKAN DAN KUALITAS DIET MAHASISWA
}

\author{
Febrina Yollanda Maretha*, Ani Margawati, Hartanti Sandi Wijayanti, Fillah Fithra Dieny
}

Departemen Ilmu Gizi, Fakultas Kedokteran, Universitas Diponegoro, J1. Prof Soedarto SH, Tembalang, Semarang, 50275 Indonesia "Penulis Penanggungjawab : Email : febrinayollanda28@gmail.com

\begin{abstract}
Background: In Indonesia, online food delivery application become quite famous in community including students. Online food delivery application helped customers to find and ordered food easier as they can manage type, amount and frequency of food. However, this application also provided a lot of unhealthy foods that may affect in eating frequency and diet quality.

Objectives: To analyze the correlation between the quantity of online food delivery application order with eating frequency and diet quality among college students.

Methods: This research was an observational study with cross sectional design. The subjects were 70 students of Diponegoro University who were selected by simple random sampling. The independent variable was online food delivery application order, while the dependent variable were eating frequency and diet quality. The confounding variable were pocket money and nutrition knowledge. Food consumption was collected using Semi Quantitative Food Frequency Questionnaire (SQ-FFQ), then converted to Diet Quality Index-International (DQI-I). Data were analyzed using Rank Spearman test.

Results: There were 97,1\% subjects who had low diet quality.There was no correlation between online food delivery application order with main meal frequency $(p=0,162)$, snacking frequency $(p=0,751)$, as well as diet quality $(p=0,869)$. There was negative correlation between pocket money and main meal frequency $(r=-0,297 ; p=0,013)$.

Conclusion: There was no correlation between online food delivery application order with eating frequency and diet quality. Personal preferences and food availability were the most influential factors on eating frequency and diet quality of college students.
\end{abstract}

Keyword: Online Food Delivery Application; Eating Frequency; Diet Quality; College Students

\begin{abstract}
ABSTRAK
Latar Belakang: Di Indonesia, aplikasi pesan antar makanan online semakin populer di berbagai kelompok masyarakat termasuk mahasiswa. Aplikasi pesan antar makanan online dapat mempermudah membeli makanan karena pembeli dapat mengatur jenis, jumlah dan frekuensi makanannya sendiri. Aplikasi ini juga menyediakan berbagai makanan yang kurang sehat sehingga dapat berpengaruh pada frekuensi makan dan kualitas diet.

Tujuan: Menganalisis hubungan penggunaan aplikasi pesan antar makanan online dengan frekuensi makan dan kualitas diet mahasiswa.

Metode: Penelitian ini adalah penelitian observasional dengan desain cross sectional. Subjek penelitian adalah mahasiwa Universitas Diponegoro sebanyak 70 orang yang dipilih melalui metode simple random sampling. Variabel bebas penelitian ini adalah penggunaan aplikasi pesan antar makanan online, sedangkan variabel terikat adalah frekuensi makan dan kualitas diet. Variabel perancu penelitian ini adalah uang saku dan pengetahuan gizi. Data konsumsi makan diambil menggunakan Semi Quantitative Food Frequency Questionnaire (SQ-FFQ) lalu dikonversi ke skor Diet Quality Index-International (DQI-I). Data diuji dengan uji korelasi Rank Spearman.

Hasil: Terdapat 97,1\% subjek yang memiliki kualitas diet buruk.Tidak ada hubungan antara penggunaan aplikasi pesan antar makanan online dengan frekuensi makan utama $(p=0,162)$, frekuensi makan selingan $(p=0,751)$ dan kualitas diet $(p=0,869)$. Ada hubungan negatif yang signifikan antara uang saku dengan frekuensi makan utama $(r=-0,297 ; p=$ $0,013)$.

Simpulan: Tidak ada hubungan antara penggunaan aplikasi pesan antar makanan online dengan frekuensi makan dan kualitas diet. Preferensi pribadi dan ketersediaan makanan di sekitar tempat tinggal menjadi faktor yang paling berpengaruh terhadap frekuensi makan dan kualitas diet.
\end{abstract}

Kata kunci: Aplikasi Pesan Antar Makanan Online; Frekuensi Makan; Kualitas Diet;Mahasiswa

\section{PENDAHULUAN}

Perkembangan teknologi internet memberikan kemudahan dalam berbagai aktivitas sehari-hari. ${ }^{1}$ Salah satu bidang yang mendapatkan dampak yang pesat dari teknologi internet adalah bidang bisnis. ${ }^{2}$ Gaya hidup terutama pola konsumsi masyarakat telah banyak mengalami perubahan karena adanya perkembangan teknologi internet. Pembelian jasa 
sudah bisa dipesan secara online, salah satunya adalah jasa pembelian makanan. ${ }^{3}$

Aplikasi pesan antar makanan online saat ini banyak digunakan oleh berbagai kalangan masyarakat termasuk mahasiswa. Kinerja layanan dan kemudahan akses menjadikan aplikasi tersebut semakin banyak digunakan. ${ }^{4}$ Keadaan seperti rasa malas, sibuk mengerjakan tugas, menghindari macet jalanan membuat konsumen memilih untuk membeli makanan melalui aplikasi pesan antar makanan online. ${ }^{5}$ Aplikasi pesan antar makanan online dapat memberikan dampak yang baik maupun buruk, tergantung bagaimana penggunanya memanfaatkan model penggunaan aplikasi ini. Pengguna aplikasi dapat memilih dan membeli makanan sesuai kebutuhannya dengan mudah dan cepat. Asupan makan yang mengandung kualitas dan kuantitas yang baik dapat memberikan efek yang baik untuk kesehatan. ${ }^{6}$ Akan tetapi saat ini terjadi peningkatan mengonsumsi makanan cepat saji setiap bulan pada kalangan mahasiswa, terutama yang berusia kurang dari 24 tahun. ${ }^{7,8}$ Aplikasi pesan antar makanan online yang memberikan akses sebesar-besarnya dapat berdampak pada tidak terkontrolnya jenis dan jumlah makanan yang dibeli. Aplikasi pesan makanan online menyediakan dengan berbagai kategori yang mudah didapat. ${ }^{4}$

Pengguna aplikasi dapat mengatur jenis, jumlah dan frekuensi makanan yang dikonsumsinya sendiri. Aplikasi ini dapat digunakan selama 24 jam, sehingga pemenuhan frekuensi makan yang baik yaitu 3 kali makanan utama dan 2 kali selingan dapat dicapai dengan mudah. Akan tetapi kemudahan membeli makanan selama 24 jam dapat berdampak pada frekuensi makan yang tidak terkontrol. Apabila mahasiswa tidak sadar terhadap kebutuhan gizi untuk mencegah peningkatan berat badan yang berlebih, maka dapat memperburuk status gizinya. ${ }^{9}$

Kualitas diet dapat dipengaruhi oleh ketersediaan dan pemilihan bahan pangan. ${ }^{10}$ Kualitas diet menentukan asupan makan telah sesuai rekomendasi atau tidak. ${ }^{11}$ Aplikasi pesan makanan online menyediakan berbagai jenis makanan dari berbagai warung makan/restoran dengan jangkauan yang luas. Makanan yang tersedia sangat bervariasi, dimulai dari makanan pokok, lauk pauk, sayuran, buah, cemilan, serta minuman dapat dibeli dengan mudah. Aplikasi pesan makanan online dapat mempermudah untuk mengatur pemilihan makanan dan meningkatkan kualitas diet, sebaliknya pemilihan makanan yang buruk dapat menyebabkan kualitas diet rendah. Kualitas diet yang rendah dikaitkan dengan konsumsi energi, gula dan lemak jenuh secara berlebih, tetapi rendah konsumsi padi-padian, buah dan sayur. ${ }^{11}$
Penelitian ini belum pernah dilakukan sebelumnya. Penelitian ini bertujuan untuk mengetahui apakah model penggunaan aplikasi pesan antar makanan online menunjukan adanya hubungan terhadap frekuensi makan dan kualitas diet mahasiswa dan apakah memberikan dampak yang positif atau negatif.

\section{METODE}

Jenis penelitian ini adalah kuantitatif menggunakan desain cross sectional. Penelitian dilakukan di wilayah Universitas Diponegoro Semarang dengan populasi mahasiswa Universitas Diponegoro. Pengambilan data dilakukan pada bulan April 2019.

Total subjek penelitian ini adalah 70 orang ditentukan menggunakan rumus analisis korelatif. Skrining subjek dilakukan dengan menyebarkan google form ke seluruh program studi melalui sosial media. Subjek yang mengisi google form sebanyak 343 orang kemudian dipilih dengan metode simple random sampling. Subjek yang dipilih harus memenuhi kriteria subjek penelitian. Kriteria inklusi penelitian ini adalah mahasiswa aktif Universitas Diponegoro, pengguna aplikasi pesan antar makanan online minimal 5 kali dalam satu bulan terakhir yang ditentukan berdasarkan hasil frekuensi penggunaan aplikasi terbanyak pada skrining awal 40 mahasiswa, tidak tinggal bersama orangtua/keluarga selama masa perkuliahan (anak kos/kontrak), tidak disediakan makanan oleh orang lain sehingga harus membeli atau menyediakan sendiri, tidak menderita penyakit yang mempengaruhi pola makan dan tidak sedang menjalankan diet khusus. Kriteria eksklusi penelitian ini adalah tidak bersedia atau tidak mampu melanjutkan penelitian.

Variabel bebas penelitian ini adalah penggunaan aplikasi pesan antar makanan online, sedangkan variabel terikatnya adalah frekuensi makan dan kualitas diet. Variabel penggunaan aplikasi pesan antar makanan online adalah frekuensi dan jenis makanan yang dibeli melalui pesan antar makanan online dalam satu bulan terakhir. Variabel frekuensi makan adalah kebiasaan frekuensi makan dalam sehari. Variabel kualitas diet adalah konsumsi makanan yang terdiri dari kategori variasi, kecukupan, moderasi dan keseimbangan keseluruhan berdasarkan formulir Diet Quality IndexInternational (DQI-I). ${ }^{12}$ Kategori variasi mengukur variasi kelompok makanan secara keseluruhan dan kelompok sumber protein. Kategori kecukupan mengukur kecukupan kelompok sayuran, buahbuahan, padi-padian, serat, protein, besi, kalsium dan vitamin C. Kategori moderasi mengukur moderasi asupan total lemak, lemak jenuh, kolesterol, natrium, dan makanan tidak berkalori. Kategori keseimbangan 
keseluruhan mengukur rasio makronutrien dan rasio asam lemak. ${ }^{12,13}$ Variabel perancu penelitian ini adalah pengetahuan gizi dan uang saku. Variabel pengetahuan gizi adalah skor yang diperoleh dari kuesioner tentang pengetahuan gizi. Variabel uang saku adalah uang yang diberikan oleh keluarga untuk memenuhi kebutuhan sehari-hari dalam satu bulan terakhir. ${ }^{14}$

Pengambilan data subjek dilakukan dengan cara mengunjungi subjek untuk melakukan wawancara kuesioner dan pengukuran antropometri. Penelitian ini telah mendapatkan keterangan layak etik dari Komisi Etik Penelitian Kesehatan Fakultas Kedokteran Universitas Diponegoro dengan No.87/EC/FK UNDIP/IV/2019. Data penggunaan aplikasi pesan antar makanan online diambil dengan metode wawancara langsung dan dilengkapi screenshot riwayat order aplikasi pesan antar makanan online selama satu bulan terakhir atas izin dan kesediaan subjek. Riwayat order yang ada pada aplikasi dilakukan konfirmasi ulang apakah ada makanan yang dibeli bersama orang lain atau apakah pernah melakukan pembelian menggunakan aplikasi orang lain, lalu diperhitungankan yang hanya dikonsumsi oleh subjek. Jenis makanan dikelompokkan menjadi 7 kelompok berdasarkan Pedoman Gizi Seimbang dengan modifikasi. Data frekuensi makan diambil dengan metode wawancara secara langsung. Data kualitas diet diambil dengan metode wawancara secara langsung menggunakan formulir Semi Quantitative Food Frequency Questionnaire ( $S Q-F F Q)$ dan dibantu dengan buku foto makanan untuk membantu estimasi porsi makanan. Data $S Q-F F Q$ dikonversi ke skor $D Q I-I .{ }^{15}$ Skor DQI-I $\leq 60 \%$ diklasifikasikan sebagai kualitas diet rendah, sedangkan skor $>60 \%$ diklasifikasikan sebagai kualitas diet tinggi. ${ }^{15}$

Data identitas diambil dengan metode wawancara langsung. Data antropometri diambil dengan cara pengukuran berat badan dan tinggi badan secara langsung menggunakan timbangan digital merek GEA dengan ketelitian $0,1 \mathrm{~kg}$ dan mikrotoa merek General Care dengan ketelitian $0,1 \mathrm{~cm}$. Pengukuran antropometri dilakukan sebanyak dua kali dan diambil nilai reratanya. Data pengetahuan gizi diambil dengan memberikan 15 pertanyaan dengan pilihan jawaban benar atau salah. Pertanyaan dibuat sendiri oleh peneliti dengan mempertimbangkan teori terkait pedoman gizi seimbang dan kualitas diet. Data uang saku diambil dengan metode wawancara secara langsung. Data alokasi uang saku untuk pembelian melalui aplikasi didapatkan dengan membagi total jumlah uang yang habis untuk pembelian melalui aplikasi dengan total uang saku/bulan. Analisis bivariat menggunakan uji Rank Spearman karena data berdistribusi tidak normal.

\section{HASIL}

Sebagian besar subjek dalam penelitian ini berjenis kelamin perempuan, memiliki status gizi normal, uang saku subjek berada dalam kategori $<\mathrm{Rp}$. 2.000.000 dan pengetahuan gizi masuk dalam kategori sedang. Karakteristik subjek penelitian disajikan dalam Tabel 1.

Tabel 1. Distribusi Frekuensi Karakteristik Subjek

\begin{tabular}{|c|c|c|}
\hline Karakteristik Responden & Frekuensi & $\%$ \\
\hline \multicolumn{3}{|l|}{ Jenis Kelamin } \\
\hline Laki-laki & 21 & 30 \\
\hline Perempuan & 49 & 70 \\
\hline \multicolumn{3}{|l|}{ Usia } \\
\hline $18-19$ tahun (remaja) & 18 & 25,7 \\
\hline $20-25$ tahun (dewasa) & 52 & 74,3 \\
\hline \multicolumn{3}{|l|}{ Status Gizi ${ }^{16}$} \\
\hline Kurus (IMT $<18,5 \mathrm{~kg} / \mathrm{m}^{2}$ ) & 11 & 15,7 \\
\hline Normal $\left(\mathrm{IMT} \geq 18,5-24,9 \mathrm{~kg} / \mathrm{m}^{2}\right)$ & 46 & 65,7 \\
\hline Berat Badan Berlebih $\left(\right.$ IMT $\left.\geq 25-<27 \mathrm{~kg} / \mathrm{m}^{2}\right)$ & 3 & 4,3 \\
\hline Obesitas $\left(\mathrm{IMT} \geq 27 \mathrm{~kg} / \mathrm{m}^{2}\right)$ & 10 & 14,3 \\
\hline \multicolumn{3}{|l|}{ Pengetahuan Gizi ${ }^{17}$} \\
\hline Kurang $<60 \%$ jawaban benar & 11 & 15,7 \\
\hline Sedang $60-80 \%$ jawaban benar & 48 & 68,6 \\
\hline Tinggi $>80 \%$ jawaban benar & 11 & 15,7 \\
\hline \multicolumn{3}{|l|}{ Uang Saku } \\
\hline$\leq$ Rp. 2.000 .000 & 46 & 65,8 \\
\hline Rp. $2.000 .001-$ Rp. 2.500 .000 & 11 & 15,7 \\
\hline$>$ Rp. 2.500 .000 & 13 & 18,5 \\
\hline
\end{tabular}




\section{Penggunaan Aplikasi Pesan Antar Makanan Online}

Rentang penggunaan aplikasi pesan antar makanan online cukup luas, yaitu 5-25 kali/bulan. Subjek lebih sering menggunakan aplikasi pesan antar makanan online pada siang hingga malam hari. Harga makanan pada aplikasi berkisar antara Rp. 1.500 pada lauk nabati - Rp. 180.000 pada kelompok jajanan. Nilai median alokasi uang saku subjek untuk membeli makanan melalui aplikasi adalah $\mathrm{Rp}$. 198.000 atau 9\% dari keseluruhan uang saku. Nilai minimal, maksimal dan median penggunaan aplikasi pesan antar makanan online disajikan dalam Tabel 2.

\section{Frekuensi Makan dan Kualitas Diet}

Sebagian besar frekuensi makan utama subjek adalah $\leq 2 \mathrm{kali} /$ hari, dan frekuensi makanan selingan adalah $1 \mathrm{kali} /$ hari. Berdasarkan wawancara, sarapan merupakan waktu makan yang paling banyak dilewatkan oleh subjek. Distribusi frekuensi berdasarkan frekuensi makan dan kualitas diet disajikan dalam Tabel 3, sedangkan skor komponen kualitas diet subjek masih tergolong rendah. Nilai minimal, maksimal, rerata dan standar deviasi kualitas diet subjek disajikan dalam Tabel 4.

\section{Hubungan Penggunaan Aplikasi Pesan Antar Makanan Online dengan Frekuensi Makan}

Berdasarkan uji Rank Spearman didapatkan bahwa tidak ada hubungan antara penggunaan aplikasi pesan antar makanan online dengan frekuensi makan utama $(p=0,162)$ dan frekuensi makan selingan $(p=0,751)$. Hasil analisis disajikan dalam Tabel 5.

Hubungan Penggunaan Aplikasi Pesan Antar Makanan Online dengan Kualitas Diet

Berdasarkan uji Rank Spearman didapatkan bahwa tidak ada hubungan antara penggunaan aplikasi pesan antar makanan online dengan skor kualitas diet dan komponennya. Hasil analisis disajikan dalam Tabel 6.

Hubungan Pengetahuan Gizi dan Uang Saku dengan Frekuensi Makan dan Kualitas Diet dengan

Berdasarkan uji Rank Spearman didapatkan bahwa ada hubungan negatif yang signifikan, semakin tinggi uang saku maka semakin rendah frekuensi makan utama $(\mathrm{r}=-0,297 ; p=0,013)$, demikian sebaliknya. Hasil analisis disajikan dalam Tabel 7.

Tabel 2. Nilai Minimal, Maksimal, dan Median Penggunaan Aplikasi Pesan Antar Makanan Online

\begin{tabular}{|c|c|c|c|}
\hline Penggunaan Aplikasi Pesan Antar Makanan Online & Minimal & Maksimal & Median \\
\hline Total Frekuensi Penggunaan aplikasi pesan antar makanan online (kali/bulan) & 5 & 25 & \\
\hline Frekuensi pembelian makanan pokok (kali/bulan) & 1 & 18 & \\
\hline Frekuensi pembelian lauk hewani (kali/bulan) & 0 & 19 & 4 \\
\hline Frekuensi pembelian lauk nabati (kali/bulan) & 0 & 5 & 0 \\
\hline Frekuensi pembelian sayur (kali/bulan) & 0 & 4 & \\
\hline Frekuensi pembelian buah (kali/bulan) & 0 & 3 & 0 \\
\hline n minuman (kali/bulan) & 0 & 7 & 0 \\
\hline Frekuensi pembelian jajanan (kali/bulan) & 0 & 9 & 1 \\
\hline Uang saku/bulan (Rp) & 700000 & 5000000 & 2000000 \\
\hline Alokasi uang saku untuk pemb & 85500 & 947900 & 198000 \\
\hline Presentasi alokasi uang saku untuk pembelian melalui aplikasi/bulan (\%) & 4 & 38 & 9 \\
\hline
\end{tabular}

Tabel 3. Distribusi Frekuensi Subjek Menurut Kategori Frekuensi Makan dan Kualitas Diet

\begin{tabular}{lcc}
\hline \multicolumn{1}{c}{ Variabel terikat } & Frekuensi & \% \\
\hline Frekuensi Makan Utama & & 60 \\
$\leq 2 \mathrm{kali} / \mathrm{hari}$ & 42 & 40 \\
$\geq 3 \mathrm{kali} / \mathrm{hari}$ & 28 & 50 \\
Frekuensi Makan Selingan & & 38.6 \\
$\leq 1 \mathrm{kali} / \mathrm{hari}$ & 35 & 11.4 \\
$2 \mathrm{kali} / \mathrm{hari}$ & 27 & 2.9 \\
$\geq 3 \mathrm{kali} / \mathrm{hari}$ & 8 & 97.1 \\
Kualitas Diet & 2 & \\
Tinggi & 68 & \\
Rendah & & \\
\hline
\end{tabular}


Tabel 4. Nilai Minimal, Maksimal, Rerata dan Standar Deviasi Kualitas Diet

\begin{tabular}{lrrr}
\hline \multicolumn{1}{c}{ Komponen Kualitas Diet } & Minimal & Maksimal & Rerata \pm SD \\
\hline Skor Variasi & 6 & 20 & $14,10 \pm 3,64$ \\
Semua kelompok makanan & 3 & 5 & $3,90 \pm 2,99$ \\
(kelompok makanan/hari)2 & 1 & 5 & $4,20 \pm 1,19$ \\
Sumber protein (jenis/hari) & 9 & 32 & $18,76 \pm 5,62$ \\
Skor kecukupan & 0 & 5 & $1,37 \pm 1,15$ \\
Sayuran (sajian/hari) & 0 & 5 & $1,53 \pm 1,23$ \\
Buah (sajian/hari) & 1 & $4,57 \pm 0,95$ \\
Padi-padian (sajian/hari) & 2 & 8 & $8,46 \pm 5,93$ \\
Serat (g/hari) & 27 & 35 & $68,13 \pm 25,50$ \\
Protein (g/hari) & 3 & 138 & $8,22 \pm 5,32$ \\
Besi (mg/hari) & 75 & 26 & $478,90 \pm 356,99$ \\
Kalsium (mg/hari) & 2 & 1861 & $62,69 \pm 63,86$ \\
Vitamin C (mg/hari) & 0 & 306 & $10,71 \pm 4,41$ \\
Skor Moderasi & 29 & 24 & $86,90 \pm 47,12$ \\
Total lemak (g/hari) & 15 & 354 & $46,73 \pm 25,05$ \\
Lemak jenuh (g/hari) & 70 & 179 & $233,46 \pm 132,55$ \\
Kolesterol (g/hari) & 179 & 866 & $835,43 \pm 609,26$ \\
Natrium (mg/hari) & 126 & 3126 & $625,41 \pm 353,47$ \\
Makanan rendah zat gizi & & $0,49 \pm 1,24$ \\
(g/hari) & 0 & 2395 & $0,37 \pm 1,09$ \\
Skor Keseimbangan Keseluruhan & 0 & $411 \pm 0,46$ \\
Makronutrien (skor) & 0 & $45,40 \pm 8,91$ \\
Asam lemak (skor) & 21 & 4 & \\
Skor Kualitas Diet & & 2 &
\end{tabular}

Tabel 5. Hubungan Penggunaan Aplikasi Pesan Antar Makanan Online dengan Frekuensi Makan

\begin{tabular}{lcccc}
\hline \multirow{2}{*}{ Variabel Bebas } & \multicolumn{2}{c}{ Frekuensi Makan Utama } & \multicolumn{2}{c}{ Frekuensi Makan Selingan } \\
\cline { 2 - 5 } & $\mathbf{r}$ & $\boldsymbol{p}^{*}$ & \multicolumn{2}{c}{$\boldsymbol{p}^{*}$} \\
\hline Penggunaan aplikasi pesan antar makanan online & 0,169 & 0,162 & $-0,039$ & 0,751 \\
\hline
\end{tabular}

*: uji Rank Spearman

Tabel 6. Hubungan Penggunaan Aplikasi Pesan Antar Makanan Online dengan Kualitas Diet

\begin{tabular}{|c|c|c|c|c|c|c|c|c|c|c|}
\hline \multirow[t]{2}{*}{ Variabel Bebas } & \multicolumn{2}{|c|}{$\begin{array}{c}\text { Skor Kualitas } \\
\text { Diet }\end{array}$} & \multicolumn{2}{|c|}{ Skor Variasi } & \multicolumn{2}{|c|}{$\begin{array}{c}\text { Skor } \\
\text { Kecukupan }\end{array}$} & \multicolumn{2}{|c|}{$\begin{array}{c}\text { Skor } \\
\text { Moderasi }\end{array}$} & \multicolumn{2}{|c|}{ Skor Keseimbangan } \\
\hline & $\mathbf{r}$ & $p *$ & $\mathbf{r}$ & $p^{*}$ & $\mathbf{r}$ & $p^{*}$ & $\mathbf{r}$ & $p^{*}$ & $\mathbf{r}$ & $p^{*}$ \\
\hline $\begin{array}{l}\text { Frekuensi penggunaan } \\
\text { aplikasi pesan antar } \\
\text { makanan online }\end{array}$ & $-0,020$ & 0,869 & 0,118 & 0,329 & $-0,06$ & 0,611 & $-0,041$ & 0,734 & $-0,05$ & 0,675 \\
\hline
\end{tabular}

Tabel 7. Hubungan Pengetahuan Gizi dan Uang Saku dengan Frekuensi Makan dan Kualitas Diet

\begin{tabular}{|c|c|c|c|c|c|c|}
\hline \multirow[t]{2}{*}{ Variabel Bebas } & \multicolumn{2}{|c|}{$\begin{array}{c}\text { Frekuensi Makan } \\
\text { Utama }\end{array}$} & \multicolumn{2}{|c|}{$\begin{array}{c}\text { Frekuensi Makan } \\
\text { Selingan }\end{array}$} & \multicolumn{2}{|c|}{ Kualitas Diet } \\
\hline & $\mathbf{r}$ & $p^{*}$ & $\mathbf{r}$ & $p^{*}$ & $r$ & $p^{*}$ \\
\hline Pengetahuan Gizi & $-0,14$ & 0,245 & 0,062 & 0,609 & 0,001 & 0,992 \\
\hline Uang Saku & $-0,29$ & 0,013 & 0,077 & 0,527 & $-0,025$ & 0,840 \\
\hline
\end{tabular}

*: uji Rank Spearman

\section{PEMBAHASAN}

Nilai median penggunaan aplikasi pesan antar makanan online subjek adalah 6 kali/bulan. Nilai median alokasi uang saku subjek untuk membeli makanan melalui aplikasi adalah Rp. 198.000 atau hanya 9\% dari keseluruhan uang saku. Selain harga, beberapa alasan subjek cenderung jarang menggunakan aplikasi pesan antar makanan online adalah hanya membeli saat ada promo, hanya saat kumpul bersama teman, dan dikenai biaya ongkos kirim. Konsumen sangat sensitif mengenai harga. Tinggi atau rendahnya harga akan menentukan keputusan seseorang dalam membeli suatu barang. ${ }^{18}$ Penelitian yang dilakukan oleh Widyastuti di Jakarta 
menunjukkan bahwa harga dan kualitas menjadi variabel yang secara signifikan mempengaruhi keputusan pembelian. ${ }^{19}$ Berdasarkan wawancara, keputusan subjek dalam membeli makanan melalui aplikasi dipengaruhi oleh harga, namun tidak mempertimbangkan kualitas karena makanan yang dijual di aplikasi maupun secara langsung memiliki kualitas yang sama.

Pada penelitian ini diketahui bahwa tidak ada hubungan antara penggunaan aplikasi pesan antar makanan online dengan frekuensi makan utama $(\mathrm{r}=$ $0,169 ; p=0,162)$ dan frekuensi makan selingan $(\mathrm{r}=$ $0,039 ; p=0,751)$. Sebagian besar subjek $(60 \%)$ memiliki kebiasaan makan utama sebanyak $\leq 2$ kali/hari dan makan selingan $\leq 1$ kali/hari. Berdasarkan wawancara, sarapan merupakan waktu makan yang paling banyak dilewatkan oleh subjek dengan alasan tidak mempunyai waktu di pagi hari, tidak terbiasa sarapan pagi atau terlambat bangun. Hasil ini sama dengan penelitian yang dilakukan oleh Niswah di Bogor memamparkan bahwa dua alasan mahasiswa tidak sarapan yang paling banyak diungkapkan adalah tidak nafsu makan dan tidak sempat karena terburu-buru di pagi hari. ${ }^{20}$

Aplikasi pesan antar makanan online lebih sering digunakan untuk membeli makan siang dan makan malam, sementara waktu makan yang paling sering dilewatkan subjek adalah sarapan. Aplikasi pesan antar makanan online dapat menjadi alternatif untuk mendapatkan akses makanan, namun apabila subjek tidak meluangkan waktu untuk makan, maka aplikasi pesan antar makanan online tidak dapat membantu meningkatkan frekuensi makan. Salah satu faktor penting yang menentukan frekuensi makan adalah pembagian waktu. ${ }^{21}$ Mahasiswa cenderung kesulitan untuk membagi waktunya antara kegiatan kuliah dan kegiatan sehari-hari. Mereka mempunyai banyak kegiatan dan tugas yang harus diselesaikan namun tidak mempunyai strategi yang tepat untuk membagi waktu. Pembagian waktu dapat dilakukan dengan menyusun kegiatan berdasarkan prioritas dan kebutuhan yang paling penting. Pembagian waktu yang baik antara istirahat, olahraga dan makan dapat meningkatkan kesehatan fisik. ${ }^{22,23}$

Pada penelitian ini diketahui bahwa tidak ada hubungan antara penggunaan aplikasi pesan antar makanan online dengan kualitas diet $(\mathrm{r}=-0,020 ; p=$ 0,869 ). Berdasarkan hasil analisis, makanan yang dibeli melalui aplikasi pesan antar makanan online hanya berkontribusi kecil terhadap pola konsumsi subjek, sehingga aplikasi pesan antar makanan online tidak dapat memberikan pengaruh terhadap kualitas diet subjek. Frekuensi konsumsi makanan pokok melalui aplikasi hanya berkontribusi sebesar 6,49\% dari frekuensi konsumsi makanan pokok secara keseluruhan. Frekuensi konsumsi daging dan unggas melalui aplikasi hanya berkontribusi sebesar $18 \%$ dari frekuensi konsumsi daging dan unggas secara keseluruhan.

Kualitas diet dalam penelitian ini dinilai berdasarkan asupan makan subjek selama satu bulan terakhir. Pada penelitian ini diketahui bahwa 97.1\% subjek memiliki skor kualitas diet rendah. Penelitian yang dilakukan oleh Retnaningrum di Semarang menunjukkan subjek obesitas maupun non obesitas memiliki kualitas diet yang rendah karena asupan cenderung tinggi lemak, rendah serat dan rendah mikronutrien. Komponen pada kategori kecukupan, moderasi, dan keseimbangan keseluruhan lah yang membuat rendahnya skor kualitas diet. ${ }^{24}$ Hasil penelitian ini juga menunjukkan hal yang sama yaitu subjek yang terdiri dari $18,3 \%$ overweight/obesitas dan $65,7 \%$ normal juga menunjukkan kualitas diet yang rendah. Skor kecukupan, moderasi dan keseimbangan keseluruhan berkontribusi pada rendahnya skor kualitas diet subjek karena kecenderungan asupan tinggi lemak, rendah sayur, rendah buah, rendah serat dan rendah mikronutrien.

Komponen skor kecukupan sayur, buah, serat, kalsium dan besi menunjukkan konsumsi subjek $<50 \%$ dari kebutuhan harian. Asupan subjek cukup bervariasi namun ternyata tidak memenuhi kecukupan kebutuhan hariannya. Rerata variasi kelompok makanan subjek hanya 3 dari 5 kelompok makanan/hari. Sebagian besar kelompok makanan yang paling sering tidak dikonsumsi tersebut adalah sayur dan buah. Sayur dan buah rerata hanya dikonsumsi 1 sajian/hari, sementara anjuran konsumsi sayur dan buah adalah 3-4 dan 2-3 sajian/hari. ${ }^{25}$ Penelitian yang dilakukan oleh Azrimaidaliza dan Idral di Padang menunjukkan bahwa semua siswa, baik laki-laki maupun perempuan tidak menyukai sayuran. ${ }^{26}$ Hasil tersebut sama dengan penelitian ini, subjek jarang mengonsumsi sayur dan buah, bahkan beberapa subjek mengaku tidak menyukai sayuran. Kemungkinan penyebab mahasiswa hanya mengonsumsi buah dan sayur dalam jumlah sedikit adalah tidak menyadari dan memperhatikan gaya hidup sehat. ${ }^{27}$ Konsumsi sayur dan buah yang rendah dapat berdampak pada rendahnya kecukupan mikronutrien. ${ }^{26}$

Sebanyak $34,4 \%$ subjek tergolong dalam kategori kecukupan total lemak berlebih $(>120 \%$ dari total energi) dan semua subjek termasuk dalam kategori kecukupan lemak jenuh tinggi ( $>7 \%$ dari total energi), artinya subjek mengonsumsi makanan yang mengandung lemak melebihi kebutuhan hariannya. Rerata skor rasio keseimbangan makronutien dan asam lemak adalah 0 . Hal tersebut sama dengan penelitian yang dilakukan oleh Nadia dan Parveen di Bahrain yang menunjukkan bahwa 
keseimbangan karbohidrat, lemak dan protein masih rendah karena tingginya konsumsi lemak. ${ }^{28}$ Penelitian yang dilakukan oleh Azrimaidaliza dan Idral di Padang menunjukan pengolahan makanan yang paling digemari siswa adalah makanan yang digoreng menggunakan minyak dan dibakar. ${ }^{26}$ Subjek dalam penelitian ini yang berasal dari berbagai daerah juga menunjukkan kecenderungan makanan yang digoreng untuk lauk hewani dan nabati seperti ayam geprek, ikan, tahu dan tempe goreng, serta jajanan gorengan seperti bakwan, pisang goreng dan martabak telur.

Selain penggunaan aplikasi pesan antar makanan online, perilaku makan dapat dipengaruhi oleh beberapa faktor yang selanjutnya berdampak pada kualitas diet. ${ }^{29}$ Menurut teori Lawrence Green, ada 3 faktor utama penentu perilaku yaitu faktor predisposisi, pemungkin dan penguat. Faktor predisposisi yang telah dianalisis dalam penelitian ini meliputi agama, jenis kelamin, daerah asal dan pengetahuan gizi namun hasilnya tidak memiliki hubungan terhadap frekuensi makan dan kualitas diet. Aplikasi pesan antar makanan online tidak dapat mempengaruhi frekuensi makan dan kualitas diet apabila subjek tidak mampu menerapkan pengetahuan gizinya. Faktor predisposisi perilaku makan subjek yang paling mempengaruhi adalah preferensi pribadi. Penelitian yang dilakukan oleh Abraham di Amerika menunjukkan bahwa Mahasiswa cenderung memilih makanan berdasarkan rasa, harga, dan kemudahan daripada mempertimbangkan nilai gizinya. ${ }^{30}$ Hasil tersebut sama dengan penelitian ini, sebagian besar subjek $(68,6 \%)$ memiliki pengetahuan gizi yang tergolong sedang, namun pemilihan makan hanya mempertimbangkan selera atau keinginan sendiri, tanpa mempertimbangkan nilai gizinya. Seseorang yang memiliki pengetahuan gizi yang baik belum tentu dapat menerapkan dan mengubah kebiasaan makannya. Pengetahuan gizi perlu dilengkapi dengan sikap dan praktik gizi agar pengetahuan tersebut dapat diterapkan sepenuhnya. ${ }^{31}$

Selain penggunaan aplikasi pesan antar makanan online, uang saku juga merupakan faktor pemungkin perilaku makan yang dianalisis dalam penelitian ini. Hasilnya menunjukkan adanya hubungan negatif yang signifikan $(\mathrm{r}=-0,297 ; p=$ 0,013), dimana semakin tinggi uang saku maka semakin rendah frekuensi makan utama, demikian pula sebaliknya. Hal ini sejalan dengan Hukum Engel yang menyatakan bahwa semakin tinggi pendapatan, maka pengeluaran untuk belanja makanan cenderung menurun dan proporsi pendapatan yang dibelanjakan untuk konsumsi non pangan akan meningkat. Pergeseran pola pengeluaran terjadi karena elastisitas pendapatan dari kebutuhan pokok makin kecil. permintaan terhadap makanan pada umumnya rendah. ${ }^{32}$ Penelitian yang dilakukan oleh Anggraeni dan Mariyanti di Jakarta menunjukan bahwa semakin besar jumlah uang saku yang dimiliki mahasiswa, maka semakin tinggi pula tingkat perilaku konsumtif yang dilakukan. ${ }^{33}$ Apabila seseorang merasa kebutuhannya telah terpenuhi, maka akan timbul kebutuhan lainnya seperti kebutuhan fashion, padahal uang saku yang diterima harus bisa memenuhi kebutuhan sampai periode yang ditentukan oleh orangtuanya. ${ }^{34,35}$ Faktor pemungkin yang diperkirakan paling berpengaruh pada perilaku makan adalah ketersediaan makanan di sekitar tempat tinggal subjek. Wilayah Kampus Universitas Diponegoro Tembalang menyediakan beragam jenis makanan yang digemari dan mudah didapatkan dengan harga yang terjangkau, sehingga tanpa melalui aplikasi pun, konsumsi subjek bergantung pada jenis makanan yang tersedia, seperti jenis makanan kombinasi, jajanan gorengan, jajanan tinggi lemak, serta minuman manis.

Faktor penguat perilaku makan yang diamati dalam penelitian ini adalah pengaruh teman sebaya. Berdasarkan wawancara, ketika subjek membeli makanan melalui aplikasi pesan antar makanan online sering terpengaruh oleh teman, namun pola konsumsi secara keseluruhan tetap paling dipengaruhi oleh preferensi pribadi. Hal ini sama dengan penelitian yang dilakukan oleh Firi di Pekanbaru menunjukkan bahwa ada hubungan yang signifikan antara pengaruh teman sebaya dengan perilaku diet mahasiswa. ${ }^{36}$ Penelitian ini tidak menganalisis faktor penguat perilaku makan lainnya seperti promosi iklan dan peran orang tua.

\section{SIMPULAN}

Tidak ada hubungan penggunaan aplikasi pesan antar makanan online dengan frekuensi makan dan kualitas diet mahasiswa. Preferensi pribadi dan ketersediaan makanan di sekitar tempat tinggal mahasiswa menjadi faktor yang paling berpengaruh terhadap frekuensi makan dan kualitas diet.

Konseling gizi diberikan untuk menemukan solusi atas permasalahan mahasiswa dalam mengatur pola makan untuk meningkatkan kualitas dietnya. Pendampingan gizi perlu diberikan kepada penjual makanan untuk menyediakan makanan yang aman dan bergizi untuk mahasiswa.

\section{DAFTAR PUSTAKA}

1. Gordon CF, Juang LP, Syed M. Internet use and well-being among college students: beyond frequency of use. J Coll Stud Dev. 2007;46(6):674-5.

2. Iulie E. The impact of the internet on the business environment. Procedia Econ Financ. 
2014;15:952-3.

3. Grunert KG, Ramus K. Consumers' willingness to buy dood through the internet. Br Food J. 2005;107(6):381-403.

4. Suryaningsih IB. Layanan aplikasi Go-Jek: validasi skala pengukuran IRSQ persepsi konsumen pada penggunaan platform Go-Food. J Bisnis dan Manaj. 2019;13(2):112-21.

5. Nurbayti. Tren pengguna aplikasi go-food di era digital. J Komunikasi, Masy dan Keamanan. 2019;1(1):1-5.

6. Ahmed EA, Ahmed AA, Huque MS, Abdulhameed A, Khan I. Obesity among university students : a cross-sectional study in Ajman , UAE. Gulf Med J. 2015;4:14-23.

7. Yahia N, Brown CA, Rapley M, Chung M. Level of nutrition knowledge and its association with fat consumption among college students. BMC Public Health. 2016;1-10.

8. Abdullah NN, Mokhtar MM, Harriszamani M, Bakar A, Al-kubaisy W. Trend on fast food consumption in relation to obesity among selangor urban community. Procedia - Soc Behav Sci. 2015;202(2014):505-13.

9. Abraham S, Noriega BR, Shin JY. College students eating habits and knowledge of nutritional requirements. J Nutr Hum Heal. 2018;2(1):2-6.

10. Muslihah N, Winarsih S, Soemardini, Zakaria A, Zainudiin. Kualitas diet dan hubungannya dengan pengetahuan gizi, status sosial ekonomi, dan status gizi. Jurnal Gizi dan Pangan. 2013;8(1):71-6.

11. Dieny FF, Widyastuti N, Fitranti DY. Sindrom metabolik pada remaja obes: prevalensi dan hubungannya dengan kualitas diet. Jurnal Gizi Klinik Indonesia. 2015;12(01):1-11.

12. Dieny FF. Permasalahan Gizi pada Remaja Putri. Yogyakarta: Graha Ilmu; 2014. 124 p.

13. De Carvalho KMB, Dutra ES, Pizato N, Gruezo ND, Ito MK. Diet quality assessment indexes. Rev Nutr, 2014;27(5):605-17.

14. Rahman N, Dewi NU, Armawaty F. Faktorfaktor yang berhubungan dengan perilaku makan pada remaja SMA negeri 1 Palu. Preventif. 2016;7(1):43-52.

15. Kim S, Haines PS, Siega-riz AM, Popkin BM. Community and international nutrition the diet quality index-international ( DQI-I ) provides an effective tool for cross-national comparison of diet quality as illustrated by China and the United States. J Nutr. 2019;133(11):3476-84.

16. Badan Penelitian dan Pengembangan Kesehatan Kementerian Kesehatan RI. Riset Kesehatan Dasar. 2013. 223-224 p.

17. Khomsan A. Teknik Pengukuran Pengetahuan
Gizi. Bogor: Institut Pertanian Bogor; 2004. 30$36 \mathrm{p}$.

18. Utami RP, Saputra H, Ekonomi AF, Medan UN, Ekonomi F, Medan UN. Pengaruh harga dan kualitas produk terhadap minat beli sayuran organik di pasar sambas Medan. J Niagawan. 2017;6(2).

19. Widyastuti P. Kualitas dan harga sebagai variabel terpenting pada keputusan pembelian sayur organik. J Bisnis dan Manaj. 2018;2(1):17-28.

20. Niswah I, Damalik MRM, Ekawidyani KR. Kebiasaan sarapan, status gizi, dan kualitas hidup remaja SMP Bosowa Bina Insani Bogor. Jurnal Gizi dan Pangan. 2014;9(10):97-102.

21. Mohiuddin A. A skipping breakfast everyday keeps well-being away. J Gastroenterol Hepatol. 2019;2(7):1-11.

22. Nasrullah S, Khan MS. The impact of time management on the students academic achievements. J Lit Lang Linguist. 2015;11:6672.

23. Hoffmacan T, Dipboye RL, Phillips AP. College student's time management: correlations with academic performance and stress. J Educ Psychol. 1990;82(4):760-8.

24. Retnaningrum G, Dieny FF. Kualitas diet dan aktivitas fisik pada remaja obesitas dan nonobesitas ". Journal of Nutrition College. 2015;4(2):469-79.

25. WHO. Nutrition in Adolescence - Issues and Challenges for the Health Sector. WHO Press. Geneva; 2005.

26. Azrimaidaliza IP. Analisis pemilihan makanan pada remaja di Kota Padang, Sumatera Barat. J Kesehat Masyrakat. 2011;6(1):17-22.

27. Schroeter C, House LA. Fruit and vegetable consumption of college students: what is the role of food fruit and vegetable consumption of college students : what is the role of food culture. J Food Distrib Res. 2017;46(3):131-45.

28. Gharib N, Rasheed P. Energy and macronutrient intake and dietary pattern among school children in Bahrain: a cross-sectional study. Nutr J. 2011;10(62).

29. Chae W, Ju YJ, Shin J, Jang S, Park E. Association between eating behaviour and diet quality: eating alone vs . eating with others. Nutrition Journal, 2018;1-11.

30. Abraham S, Noriega BR, Shin JY. College students eating habits and knowledge of nutritional requirements . J Nutr Hum Heal. 2018;2(1):13-7.

31. Azizi M, Aghaee N, Ebrahimi M, Ranjbar K. Nutrition knowledge, the attitude and practices of college students. Phys Educ Sport. 
2011;9:349-57.

32. Nicholson W. Mikroekonomi Intermediate. Jakarta: Erlangga; 2002.

33. Anggreini R, Mariyanti S. Hubungan antara kontrol diri dan perilaku konsumtif mahasiswa universitas esa unggul. J Psikol. 2014;12.

34. Lisma N. Analisis perilaku konsumsi mahasiswa ditinjau dari motif bertransaksi ( studi kasus pada mahasiswi s1 pendidikan ekonomi fakultas ekonomi Universitas Negeri Malang angkatan tahun 2012 ). Jurnal Pendidikan Ekonomi.
2016;9(1):41-50.

35. Fiqriyah R, Wahyono H, Inayati R. Pengaruh pengelolaan uang saku, modernitas, kecerdasan emosional, dan pemahaman dasar ekonomi terhadap rasionalitas perilaku konsumsi siswa kelas X IIS MAN 1 Malang. Jurnal Pendidikan Ekonomi. 2016;09(1):1-10.

36. Firi RP. Pengaruh teman sebaya, pengetahuan media masa terhadap perilaku diet mahasiswi STIKES Payung Negeri Pekanbaru. J Endur. 2018;3(1):162-8. 